\title{
Effects of Soil Nitrogen and Atmospheric Carbon Dioxide on Wheat streak mosaic virus and Its Vector (Aceria tosichella Kiefer)
}

Zachariah J. Miller, Western Agricultural Research Center, Montana State University, Corvallis 59828; and Erik A. Lehnhoff and Fabian D. Menalled, Department of Land Resources and Environmental Sciences, and Mary Burrows, Department of Plant Sciences and Plant Pathology, Montana State University, Bozeman 59717

\begin{abstract}
Miller, Z. J., Lehnhoff, E. A., Menalled, F. D., and Burrows, M. 2015. Effects of soil nitrogen and atmospheric carbon dioxide on Wheat streak mosaic virus and its vector (Aceria tosichella Kiefer). Plant Dis. 99:1803-1807.

Management of vector-borne plant viruses requires understanding how abiotic (e.g., resource availability) and biotic (e.g., virus-vector interactions) factors affect disease via effects on epidemiological parameters that drive disease spread. We conducted two complementary experiments using Wheat streak mosaic virus (WSMV): (i) a field study to determine the effects of nitrogen $(\mathrm{N})$ fertilization on winter wheat (Triticum aestivum L.) susceptibility to WSMV infection and (ii) a growth chamber study to evaluate the effects of $\mathrm{N}$ and carbon dioxide $\left(\mathrm{CO}_{2}\right)$ enrichment on population growth rates of the wheat curl mite (WCM), the vector of WSMV, and whether the effects of nutrient addition on WCM

reproduction were modified by WSMV infection. The relationship between $\mathrm{N}$ fertilization and plant susceptibility to WSMV infection was nonlinear, with infection rates increasing rapidly as soil nitrate increased from 0 to $20 \mathrm{ppm}$ and more gradually at higher nitrate concentrations. In the growth chamber study, N fertilization increased WCM population growth rates when the vectors transmitted WSMV but had the opposite effect on nonviruliferous mites. $\mathrm{CO}_{2}$ enrichment had no observable effects on WCM populations. These results suggest that, whereas the spread of WSMV is facilitated by $\mathrm{N}$ addition, increases in atmospheric $\mathrm{CO}_{2}$ may not directly alter WCM populations and WSMV spread.
\end{abstract}

Management of crop disease often utilizes practices such as pesticide use or plant resistance that directly reduce pathogen or vector populations. Yet, sole reliance on these disease control practices may not be sustainable due to, among other issues, pesticide resistance, nontarget effects, and increased production costs (Tilman et al. 2002) as well as changing environmental conditions associated with predicted climate scenarios (Ziska and Runion 2007). Consequently, there is growing interest in managing crop disease via indirect mechanisms such as nutrient availability that alter the host or environment in ways that inhibit disease spread or impact (Dordas 2008; Thresh 1982). Research in this area has demonstrated that indirect disease control mechanisms can simultaneously reduce disease impacts and pesticide inputs (Leung et al. 2003), providing the basis for effective, ecologically based disease management practices.

In agricultural systems, much epidemiological research on indirect disease control has focused on the impact of nutrient availability on plant susceptibility to infection and disease transmission rates (Dordas 2008). This research has shown that, although many types of diseases can be affected by nutrient availability, this impact depends on the specific host-pathogen interaction and the type and quantity of nutrients added (Huber and Watson 1974; Walters and Bingham 2007). For example, viral replication within the plant host is nutrient limited and, typically, maximal viral replication rates occur under conditions favoring optimal plant growth (Hull 2002). Studies of the effects of nutrient addition on viral replication have shown that effects vary by nutrient and pathosystem, with nitrogen and phosphorus addition generally increasing viral titer and more varied results for potassium and other nutrients (Pennazio and Roggero 1997). Similarly, research suggests that risk of crop disease may increase, decrease, or remain the same in response to increasing concentrations of atmospheric carbon dioxide $\left(\mathrm{CO}_{2}\right)$, depending on the pathogen system (Luck et al. 2011).

Corresponding author: M. Burrows; E-mail: mburrows@montana.edu

Accepted for publication 10 June 2015.

http://dx.doi.org/10.1094/PDIS-01-15-0033-RE

(C) 2015 The American Phytopathological Society
Several hypothesis have been proposed to explain the effects of nutrient addition on disease and the variability in responses among host-pathogen interactions (Dordas 2008). The reproduction of pathogens and pathogen vectors is nutrient limited; thus, increasing nutrient supply rates to plants may stimulate pest reproduction. Plant defenses can also be altered by nutrient supply (Kytö et al. 1996). Rather than the availability of single nutrients, the relative availability of nutrients may drive disease dynamics. The Ecological Stoichiometric theory predicts that pathogen replication and vector reproduction depend on ratios of nutrients available in host plant tissues, with optimal growth when the elemental composition of the host cells matches the composition of the pathogen or vectors. Deviations from these ratios in host tissues should retard growth of the virus or vectors (Sterner and Elser 2002). Experiments in aquatic host-pathogen systems have supported the prediction that infection dynamics are slowed by high carbon to phosphorous and carbon to nitrogen $(\mathrm{N})$ ratios (Clasen and Elser 2007; Frost et al. 2008). Similarly, insect herbivore growth rates have been shown to depend on similar elemental ratios in host plants (Zehnder and Hunter 2009).

The combined effects of $\mathrm{N}$ and $\mathrm{CO}_{2}$ fertilization on the spread of vector-borne plant viruses may be particularly complex and variable. Understanding these effects is critical because $\mathrm{N}$ fertilization rates and atmospheric $\mathrm{CO}_{2}$ concentrations have increased significantly in recent years (Foley et al. 2005; Tilman et al. 2002). Separately and together, these nutrients have the potential to alter disease spread through direct effects on plant, vector, and virus growth as well as the interactions among these three organisms.

Although the effects of fertilization on viral replication have been well documented (Pennazio and Roggero 1997), little work has been done on how host nutrition affects plant susceptibility to vectorborne viruses. Recently, the first evidence was reported where phosphorous addition reduced infection rates of one species of barley yellow dwarf virus (Cereal yellow dwarf virus) but not another (Barley yellow dwarf virus) (Lacroix et al. 2014). $\mathrm{N}$ and $\mathrm{CO}_{2}$ addition can also affect vector-borne plant viruses via their effects on vector population dynamics that are, in turn, mediated through changes in plant nutrition (i.e., plant-vector interactions). Vector populations are often $\mathrm{N}$ limited, and $\mathrm{N}$ addition can increase vector numbers (Kagata and Ohgushi 2006). $\mathrm{CO}_{2}$ concentrations can have large effects on vector populations through altering plant growth and nutritive value 
but responses depend on both plant and plant-feeding vector species (Coviella and Trumble 1999; Fuhrer 2003), with phloem- and cellfeeding arthropods generally benefiting from elevated $\mathrm{CO}_{2}$ (Bezemer and Jones 1998). In addition, $\mathrm{N}$ and $\mathrm{CO}_{2}$ fertilization can inhibit disease when the addition of these nutrients enhances the production of $\mathrm{N}$ - or C-based defense compounds in the host plant (Kytö et al. 1996). Finally, although many viruses alter vector fecundity and behavior to facilitate transmission (Bosque-Pérez and Eigenbrode 2011; Jiménez-Martínez et al. 2004), sparse knowledge exists on how $\mathrm{CO}_{2}$ and $\mathrm{N}$ fertilization may individually and jointly alter these virus-vector interactions.

Here, we report the results of a series of complementary experiments examining the effects of $\mathrm{CO}_{2}$ and $\mathrm{N}$ fertilization on host susceptibility and vector fecundity in the Wheat streak mosaic virus (WSMV) system. These factors drive the spread of WSMV, which causes yield losses in cereals around the globe (Navia et al. 2013) and is transmitted by the wheat curl mite (WCM, Aceria tosichella). Management of the WSMV-WCM complex in small grain systems relies primarily on prevention and is complicated by the vector and virus having a broad range of hosts that includes many noncrop grasses (Navia et al. 2013). We tested, (i) in a field experiment, the effects of $\mathrm{N}$ fertilization on the susceptibility of winter wheat (Triticum aestivum $\mathrm{L}$.) to WSMV and, (ii) in a growth chamber study, the individual and combined effects of $\mathrm{CO}_{2}$ and $\mathrm{N}$ fertilization on WCM population growth. In addition, we assessed, (iii) in growth chamber conditions, whether the effects of $\mathrm{CO}_{2}$ and $\mathrm{N}$ addition on vector population dynamics were altered by the presence of WSMV. To our knowledge, this represents the first research on the effects of $\mathrm{N}$ on crop susceptibility to WSMV infection and the first work on the joint effects of $\mathrm{N}$ and $\mathrm{CO}_{2}$ on virus-vector-host interactions.

\section{Materials and Methods}

Effects of $\mathbf{N}$ fertilization on the susceptibility of wheat to WSMV. The field experiment was conducted at the Montana State University Arthur H. Post Research Farm, four miles west of Bozeman $\left(45^{\circ} 40^{\prime} 29^{\prime \prime} \mathrm{N}, 111^{\circ} 09^{\prime} 14^{\prime \prime} \mathrm{W}, 1,423 \mathrm{~m}\right.$ in elevation). The soil at the site is an Amsterdam-Quagle silt loam, $\mathrm{pH}$ 7.8. Average monthly temperatures and cumulative precipitation during the experiment were similar to the means for the site based on data from 1966 to the present (Orloff et al. 2013). The experiment consisted of two trials conducted over two winter wheat crops, fall 2008 to summer 2009 and fall 2009 to summer 2010.

Design. In each trial, $\mathrm{N}$ fertilization treatments were assigned in a randomized complete block design with four replicated blocks. Each block consisted of 20 winter wheat ('Neely') plots ( $1.5 \mathrm{~m}$ wide by $6 \mathrm{~m}$ long) that varied in $\mathrm{N}$ availability (i.e., treatments). To create a gradient of $\mathrm{N}$ availability, plots were fertilized at different rates based on residual soil $\mathrm{N}$ sampled in the previous fall. These samples consisted of six composited soil cores $(3.8 \mathrm{~cm}$ in diameter by $91 \mathrm{~cm}$ deep) per block. In 2008-09, plots received one of two rates (no $\mathrm{N}$ added and $\mathrm{N}$ added at $291 \mathrm{~kg} \mathrm{ha}^{-1}$ ) of fall-applied urea. In 2009-10, plots received four rates (no $\mathrm{N}$, and $\mathrm{N}$ added at either 112,224 , or $336 \mathrm{~kg} \mathrm{ha}^{-1}$ ) of spring-applied urea. $\mathrm{N}$ availability was sampled in June 2009 and 2010 by taking five systematically located soil cores ( $45 \mathrm{~cm}$ deep and $2 \mathrm{~cm}$ diameter) in each plot, with each core taken from a different interrow space following a diagonal pattern across the plot. Soil samples were combined and homogenized for each plot. Soil N availability ranged from 1.3 to $47 \mathrm{ppm}$ and was similar between years (analysis of variance [ANOVA] year effect $\left.\mathrm{F}_{1,158}=0.003, P>0.9\right)$. All soil cores were analyzed by Agvise Laboratories (Northwood, ND).

Wheat was planted with a no-till drill with seven rows spaced $0.25 \mathrm{~m}$ apart on 10 October 2008 and 6 October 2009 at a seeding rate of $67 \mathrm{~kg} \mathrm{ha}^{-1}, 3$ weeks after an application of a broadspectrum herbicide (glyphosate, $0.43 \mathrm{~kg}$ a.i. $\mathrm{ha}^{-1}$ ). Starter fertilizer (N-P-K at 6-19-28 $\mathrm{kg} \mathrm{ha}^{-1}$ ) was applied in the furrow at seeding. The inner five rows of each plot were mechanically inoculated with a WSMV isolate collected in Conrad, MT (GenBank accession HM535796; hereafter, Conrad I) following the procedures detailed by Miller et al. (2014). In brief, large quantities of WSMV-infected spring wheat were grown in the greenhouse. Plant sap containing the virus was extracted and mixed with buffer and carborundum, and plants were mechanically inoculated with a custom paint sprayer with an air compressor at 80 PSI. Inoculations occurred in the spring on 21 May 2009 and 19 May 2010, when wheat was at Feekes 3 to 4. Although fall infection with WSMV is more common than spring infection, spring infection does occur. It was also necessary to inoculate following fertilization to gauge the effects of that treatment.

The metric used to assess wheat susceptibility to WSMV inoculation was the proportion of plants infected measured approximately 1 month after inoculation. In all, 10 to 15 flag leaves were randomly sampled from the inner five rows of each plot on 25 June 2009 and 21 June 2010. All leaves were processed individually with enzymelinked immunosorbent assay (ELISA) as described by Ito et al. (2012). The mean and standard error of the absorbance (optical density [OD] at $405 \mathrm{~nm}$ ) values of six negative controls (healthy wheat collected from uninoculated plots) on each plate were used to identify infected plants. These values were used to set a probabilistic OD threshold at three standard deviations above the mean, beyond which plants were considered infected.

Statistical analysis of field trials. The relationship between WSMV incidence and $\mathrm{N}$ availability was tested using a logistic regression model. The model tested whether WSMV incidence varied by year and with $\mathrm{N}$ availability, and whether the relationship between $\mathrm{N}$ and incidence varied between years (i.e., $\mathrm{N}$-year interaction). Soil nitrate concentration ( $\mathrm{ppm}$ ) was natural log-transformed prior to the analysis. The effects of $\mathrm{N}$, year, and their interaction were assessed using a $\chi^{2}$ test of the change in residual deviance $(\Delta D)$ in a sequential deletion of the terms from the full model (Hosmer and Lemeshow 2000). Preliminary analysis revealed that replicated blocks did not explain a significant amount of deviance and their random effects were removed from the model. In addition, two significant outliers were detected based on the Bonferroni corrected test of Studentized residuals and were removed prior to the analysis.

Effects of WSMV, $\mathrm{CO}_{2}$, and $\mathrm{N}$ on vector population growth. A growth chamber study was used to evaluate (i) the effects of $\mathrm{N}$ and $\mathrm{CO}_{2}$ fertilization on WCM population growth and (ii) whether the effects of nutrient addition were modified by the presence of WSMV in the WCM and wheat plant. The study consisted of two trials with WCM populations assigned to three treatments $\left(\mathrm{N}, \mathrm{CO}_{2}\right.$, and WSMV; see details below) in a randomized, factorial design. Each treatment combination was replicated 10 and 9 times in the first and second trial, respectively.

In this study, the experimental unit was a WCM population reared on an individual spring wheat ('Reeder') plants. Single plants were grown in pots $(10 \mathrm{~cm}$ in diameter by $14 \mathrm{~cm}$ tall) filled with $625 \mathrm{ml}$ of a 2:1:1 mixture (by volume) of sand, peat, and top soil and placed on individual trays. The soil mixture was leached to reduce residual soil $\mathrm{N}$ to 4 to $6 \mathrm{ppm}$ by repeatedly saturating the soil with water and letting the water drain out of the soil. To ensure that $\mathrm{N}$ was the only limiting nutrient, all pots were fertilized with phosphorous and potassium to recommended levels ( 25 and $200 \mathrm{ppm}$, respectively). All pots were caged to prevent WCM movement. The cages were constructed of clear plastic containers $(20 \mathrm{~cm}$ tall and $12 \mathrm{~cm}$ in diameter) with three vents $\left(10 \mathrm{~cm}^{2}\right.$ per vent) covered with a $30-\mu \mathrm{m}$ mesh. Pots were placed in trays and were watered by filling the trays with $2 \mathrm{~cm}$ of water on a regular basis (two to three times per week). Plants were grown in growth chambers (Conviron CMP 6050) under a photoperiod of $16 \mathrm{~h}$ (day) and $8 \mathrm{~h}$ (night) held at 24 and $10^{\circ} \mathrm{C}$, respectively.

The $\mathrm{N}$ fertilization treatment had two levels, high $\left(219 \mathrm{~kg} \mathrm{ha}^{-1}\right.$, $200 \mathrm{ppm}$ ) and low (17 $\left.\mathrm{kg} \mathrm{ha}^{-1}, 35 \mathrm{ppm}\right)$, added as urea at planting. These rates were set to approximate typical fertilization rates in wheat (high) and an unfertilized field (low). $\mathrm{CO}_{2}$ treatments consisted of two levels: ambient (385 ppm) and elevated (1.8× ambient, $700 \mathrm{ppm})$. The elevated $\mathrm{CO}_{2}$ concentration represented predicted values to be reached in 50 to 100 years (Nakicenovic and Swart 2000). $\mathrm{CO}_{2}$ treatments were applied by randomly assigning WCM populations (pots) to one of two growth chambers that were set to maintain each of the target $\mathrm{CO}_{2}$ concentrations. Finally, the WSMV infection treatment also consisted of two levels: WCM populations 
that were either viruliferous or aviruliferous. Locally collected, aviruliferous mites were maintained in a growth chamber on 'Choteau' spring wheat, as described by Ito et al. (2012). Mites were transferred to wheat plants that were either healthy or mechanically infected with WSMV. The virus status of these two WCM populations was tested by transferring mites to 25 wheat plants per treatment and measuring whether or not the transfer resulted in WSMV infection using the ELISA protocols described above. Virus-free WCM transfers never resulted in a WSMV infection and transfers from the WSMVinfected vectors always resulted in infection.

To estimate the WCM population growth rates, mites were transferred onto two- to three-leaf stage wheat plants by attaching a miteinfested leaf segment harvested from the colonies described above to a leaf of the experimental wheat plant with a small paper clip. After $24 \mathrm{~h}$, the leaf segment was removed and the number of mites that moved onto the inoculated plant (i.e., initial WCM population size) was counted using a $\times 20$ hand lens. After 2 to 3 weeks, the final population size of the WCM was estimated by counting all WCM on the plant under a dissection scope using $\times 30$ to $\times 40$ magnification.

Statistical analysis of growth chamber trials. The population growth rate ( $\lambda=$ mites produced per mite per day) was estimated using initial $\left(\mathrm{N}_{0}\right)$ and final $\left(\mathrm{N}_{\mathrm{t}}\right)$ numbers of mites and number of days $(\mathrm{t})$ that mites were present on the plant using the population growth model $\mathrm{N}_{\mathrm{t}}=\lambda^{\mathrm{t}} \times \mathrm{N}_{0}$.

When growth rate $(\lambda)$ is greater than 1 , mite populations are increasing; a growth rate $=1$ indicates no change; and values lower than 1 suggest a decrease in population size. Replicates (i.e., experimental units) were not used when the WCM transfer was not successful, as determined by the absence of mites on the host plant after the initial count. This occurred on $8 \%$ (12 of 152) of the replicates and transfer failure rates were not associated with any of the treatments $(P>0.05)$. The remaining $140 \mathrm{WCM}$ population growth rates were analyzed using an ANOVA model with fixed effects of trial, $\mathrm{N}, \mathrm{CO}_{2}$, and WSMV in a fully crossed design. Effects of the treatments were similar across trials (all trial-treatment interactions, $P>0.1$, results not shown) and data were then reanalyzed with random effect of trial and fixed effects of $\mathrm{N}, \mathrm{CO}_{2}$, and WSMV treatments. One significant outlier was detected based on the Bonferroni corrected test of Studentized residuals and was removed prior to the analysis. For interaction terms that had significant effects $(P<0.05)$ in the ANOVA, means were compared using Tukey's honest significant difference. All analyses were performed using R version 2.15 (R Foundation for Statistical Computing, Vienna).

\section{Results}

Effects of $\mathbf{N}$ fertilization on the susceptibility of wheat to WSMV. In field conditions, winter wheat susceptibility to WSMV infection increased with log-transformed soil nitrate concentration, indicating a nonlinear relationship between soil $\mathrm{N}$ and susceptibility

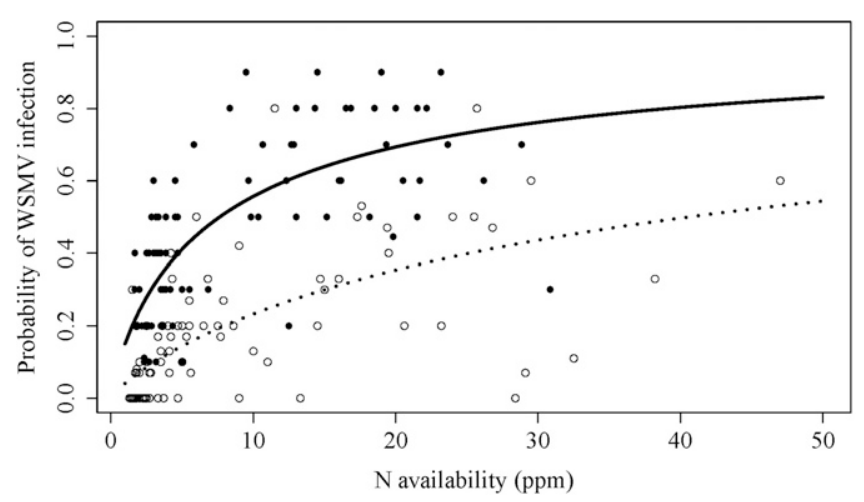

Fig. 1. Relationship between soil nitrate concentration and probability of Wheat streak mosaic virus (WSMV) infection in winter wheat after mechanical inoculation. Each data point represents measures from a single field plot. Closed circles and solid line denote the data and relationship for 2009 to 2010. Open circles and dashed line denote data and relationship for 2010 to 2011.
( $\Delta \mathrm{D}=197.4, \mathrm{df}=1, P<0.0001)$. The relationship was consistent between years and trials (interaction between year and $\ln [\mathrm{N}], \Delta \mathrm{D}=0.3$, $\mathrm{df}=1, P>0.5)$. Infection rates differed between years $(\Delta \mathrm{D}=154.1, \mathrm{df}=$ $1, P<0.0001$ ), averaging $46 \%$ in 2009 and $19 \%$ in 2010 (Fig. 1). Averaged between years, infection rates rose from 8.2 to $53.2 \%$ for soil nitrate at 0 to $20 \mathrm{ppm}$, an over-sixfold increase in the density of infected plants. Further increases in soil nitrate concentration produced smaller increases in WSMV infection rates. As $\mathrm{N}$ increased from 20 to $40 \mathrm{ppm}$, infection rates increased by less than $15 \%$, to $67.2 \%$.

Effects of WSMV, $\mathrm{CO}_{2}$, and $\mathrm{N}$ on vector population growth. In growth chamber conditions, $\mathrm{CO}_{2}$ addition did not alter WCM population growth rates (Table 1). WCM population growth was affected by $\mathrm{N}$ fertilization of the host plants but this effect was modified by the presence of WSMV in the vector and host plant (Table 1). In aviruliferous WCM populations, $\mathrm{N}$ fertilization reduced growth rates from 1.18 mites per mite per day in the low-N treatment to 1.13 (95\% confidence interval $[\mathrm{CI}] \pm 0.03$ ) in the high-N treatment (Fig. 2). In WCM populations that carried WSMV, the magnitude of the effect of $\mathrm{N}$ fertilization was similar but the direction (sign) of effect was reversed. Specifically, rather than reducing vector population growth rates, $\mathrm{N}$ addition increased the growth rates from 1.11 to 1.20 $(95 \% \mathrm{CI} \pm 0.3)$ mites per mite per day in viruliferous populations (Fig. 2).

\section{Discussion}

Understanding the effects of nutrient addition on host-vectorvirus interactions and crop disease transmission is critical to developing sustainable, ecologically based disease management practices. In this study, we explored the effects of $\mathrm{N}$ addition on susceptibility of wheat to WSMV infection and the interactive effects of WSMV, N,

Table 1. Results of the analysis of variance testing the effect of nitrogen and carbon dioxide $\left(\mathrm{CO}_{2}\right)$ addition and Wheat streak mosaic virus (WSMV) infection on wheat curl mite (WCM) population growth rates

\begin{tabular}{lrrrc}
\hline Source & $\mathbf{d f}^{\mathbf{a}}$ & MS & $\boldsymbol{F}$ & $\boldsymbol{P}$ \\
\hline Trial & 1 & 0.016 & $\ldots$ & $\ldots$ \\
Nitrogen (N) & 1 & 0.016 & 3.6 & 0.06 \\
$\mathrm{CO}_{2}(\mathrm{C})$ & 1 & 0.004 & 0.9 & $>0.3$ \\
$\mathrm{WSMV}(\mathrm{V})$ & 1 & $<0.001$ & 0.0 & $>0.8$ \\
$\mathrm{~N} \times \mathrm{C}$ & 1 & $<0.001$ & 0.0 & $>0.8$ \\
$\mathrm{C} \times \mathrm{V}$ & 1 & 0.005 & 1.1 & $>0.3$ \\
$\mathrm{~N} \times \mathrm{V}$ & 1 & 0.152 & 33.9 & $<0.000001$ \\
$\mathrm{~N} \times \mathrm{C} \times \mathrm{V}$ & 1 & $<0.001$ & 2.0 & $>0.1$ \\
Error & 131 & 0.004 & $\ldots$ & $\ldots$ \\
\hline
\end{tabular}

a Degrees of freedom.

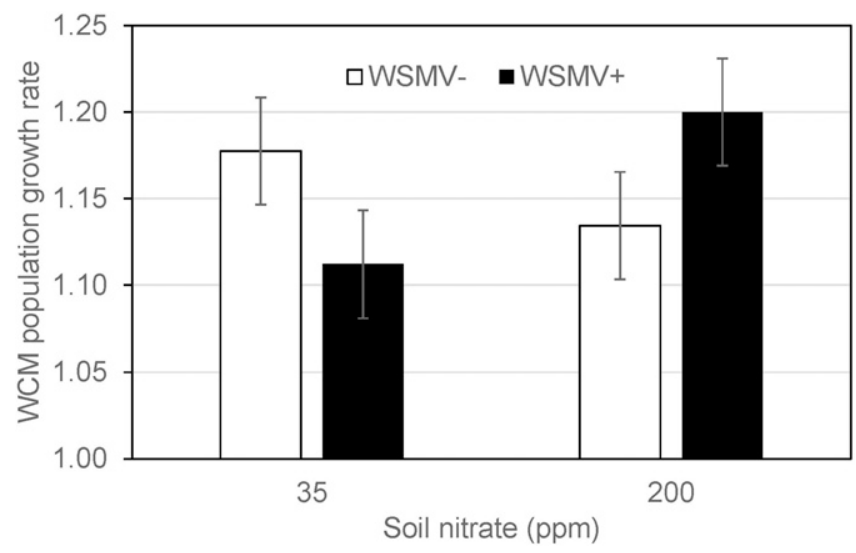

Fig. 2. Interactive effects of Wheat streak mosaic virus (WSMV) infection and nitrogen fertilization of wheat curl mite (WCM) population growth rates. WCM population growth rates (y-axis) are measured in mites per mite per day. WCM populations were either aviruliferous (WSMV-) or viruliferous (WSMV+). 
and $\mathrm{CO}_{2}$ addition on the mite vector. Our field results demonstrate that $\mathrm{N}$ availability increases wheat susceptibility to WSMV infection. However, mechanical inoculation of WSMV may not provide an accurate estimate of plant susceptibility to virus transmitted by WCM (Ito et al. 2012). Further research is needed to test the generality of the increasing susceptibility due to soil $\mathrm{N}$ observed here.

In growth chamber conditions, $\mathrm{CO}_{2}$ addition did not alter vector population growth, suggesting that WSMV risk will not be directly affected by increasing concentrations of atmospheric $\mathrm{CO}_{2}$. The effects of $\mathrm{CO}_{2}$ on WCM growth have not been tested previously. The lack of a $\mathrm{CO}_{2}$ effect is surprising given that vector populations are commonly $\mathrm{N}$ limited and $\mathrm{CO}_{2}$ addition has been shown to decrease shoot $\mathrm{N}$ concentration in wheat (Thompson et al. 1993). This result, taken in context with previous research, also suggests that the effects of $\mathrm{CO}_{2}$ enrichment on vector populations are complex and vary widely between plant and vector species (Bezemer and Jones 1998; Coviella and Trumble 1999). Phloem-feeding aphids have been found to reproduce more rapidly (Awmack et al. 1997; Bezemer et al. 1998) on plants grown in elevated $\mathrm{CO}_{2}$ but other studies have found negative or no effects (Bezemer et al. 1998; Docherty et al. 1997). There have been fewer studies of the effects of $\mathrm{CO}_{2}$ on whole-cell-feeding arthropods such as the WCM but there, too, responses have been mixed. Whole-cell-feeding insect populations (i.e., whiteflies [Bemisia and Trialeurodes spp.] and thrips [Frankliniella spp.]) are either not affected (Butler et al. 1986; Heagle 2003; Hughes and Bazzaz 1997) or negatively affected by the addition of $\mathrm{CO}_{2}$ (Tripp et al. 1992). Similarly, previous studies of the effects of $\mathrm{CO}_{2}$ on plant-cell-feeding mites have had mixed results. $\mathrm{CO}_{2}$ enrichment increased population growth rates of two-spotted spider mites (Tetranychus urticae Koch) on clover (Heagle et al. 2002) but had the opposite effect when mites fed on common bean (Joutei et al. 2000).

The WCM population growth rate responded to $\mathrm{N}$ fertilization but the effects were contingent on WSMV infection and can be described as a virus-vector mutualism that is conditional on $\mathrm{N}$ limitation. Although, at the high $\mathrm{N}$ rates, the interaction between virus and vector was mutually beneficial, at the low $\mathrm{N}$ rates, the transmission was beneficial for the virus but detrimental for the vector. In partial accordance with our results, Altieri and Nicholls (2003) observed increased population growth of plant-feeding mites (spider mites, Tetranychidae) following $\mathrm{N}$ addition. To our knowledge, ours is the first study to show that the virus-vector interactions can be altered by host nutrient supply.

The mechanisms for the N-dependent effects of WSMV on the WCM vector are not known but are likely mediated through the host plant responses to viral infection and N. Previous studies have shown that performance of insects that transmit plant viruses is positively correlated with concentrations of host plant N, proteins, or free amino acids (Bosque-Pérez and Eigenbrode 2011) which, in turn, are associated with increased rates of leaf senescence (Johnson et al. 2003). During senescence, proteins are degraded and translocated from the mesophyll cells (Lim et al. 2007), making N more available to leaffeeding arthropods. This may explain the increased WCM growth rates on $\mathrm{N}$-stressed plants in the absence of WSMV. When plants were infected, the vector and virus may have been competing for limited plant resources, reducing WCM growth rates. However, previous research suggests that WSMV effects on WCM are more complex than simply being responses to increased plant nutrient content. For example, WSMV infection does not improve the performance of aphid species (Rhopalosiphum padi L. and Schizaphis graminum Rondani) that do not vector WSMV (Jiménez-Martínez et al. 2004; Michels et al. 1994).

From a disease management perspective, our results suggest that the impacts of $\mathrm{N}$ fertilization on WSMV spread may be large because $\mathrm{N}$ addition increased wheat susceptibility to WSMV infection. In addition, the increase in vector population growth rate associated with $\mathrm{N}$ resulted in many more viruliferous mites which, in turn, may result in large differences in number of vectors. For example, if mite populations began with two WCM per plant, after 6 weeks, the well-fertilized plant would support over 4,200 mites, 24 times more than would be found on an unfertilized wheat plant (174 mites, on average). Thus, $\mathrm{N}$ fertilization could result in an increase in the numbers of viruliferous WCM that disperse out of a wheat field at the end of the growing season, augmenting the risk of between- and within-fields transmission and disease persistence (Thomas and Hein 2003).

Exploiting the positive relationship between $\mathrm{N}$ fertilization and disease management poses difficulties to maximize crop yield. In the WSMV-WCM system, modifying the timing and amount of fertilization may provide effective disease management. For example, the results presented here suggest that, because WCM typically immigrate into winter wheat fields in the fall, avoiding fertilization at this time of the year can prevent rapid population growth. This practice would benefit producers because winter wheat fertilization can be split between fall and spring or delayed until spring with little effect on yield (Mahler et al. 1994).

\section{Acknowledgments}

This work was supported with funding from the Montana Fertilizer Advisory Committee and the USDA-Crops at Risk Program. We thank E. Davis, M. Moffett $\mathrm{N}$. Orloff, and D. Brown for providing invaluable assistance in field and lab operations; and the students who spent countless hours at the microscopes counting mites.

\section{Literature Cited}

Altieri, M. A., and Nicholls, C. I. 2003. Soil fertility management and insect pests Harmonizing soil and plant health in agroecosystems. Soil Tillage Res. 72: 203-211.

Awmack, C. S., Harrington, R., and Leather, S. R. 1997. Host plant effects on the performance of the aphid, Aulacorthum solani (Kalt.) (Homoptera: Aphididae) at ambient and elevated $\mathrm{CO}_{2}$. Glob. Change Biol. 3:545-549.

Bezemer, T. M., and Jones, T. H. 1998. Plant-insect herbivore interactions in elevated atmospheric $\mathrm{CO}_{2}$ : Quantitative analyses and guild effects. Oikos 82: 212-222.

Bezemer, T. M., Jones, T. H., and Knight, K. J. 1998. Long-term effects of elevated $\mathrm{CO}_{2}$ and temperature on populations of peach potato aphid, Myzus persicae, and its parasitoid, Aphidium matricariae. Oecologia 116:128-135.

Bosque-Pérez, N. A., and Eigenbrode, S. D. 2011. The influence of virus-induced changes in plants on aphid vectors: Insights from luteovirus pathosystems. Virus Res. 159:201-205.

Butler, G. D., Kimball, B. A., and Mauney, J. R. 1986. Populations of Bemisia tabaci (Homoptera: Aleyrodidae) on cotton grown in open-top field chambers enriched with $\mathrm{CO}_{2}$. Environ. Entomol. 15:61-63.

Clasen, J. L., and Elser, J. J. 2007. The effects of host Chlorella NC64A carbon: phosphorous ratio on the production of Paramecium bursaria Chlorella Virus-1. Freshwater Biol. 52:112-122.

Coviella, C. E., and Trumble, J. T. 1999. Effects of elevated atmospheric carbon dioxide on insect-plant interactions. Conserv. Biol. 13:700-712.

Docherty, M., Wade, F. A., Hurst, D. K., Whittaker, J. B., and Lea, P. L. 1997 Responses of tree sap-feeding herbivores to elevated $\mathrm{CO}_{2}$. Glob. Change Biol. 3:51-59.

Dordas, C. 2008. Role of nutrients in controlling plant diseases in sustainable agriculture: A review. Agron. Sustain. Dev. 28:33-46.

Foley, J. A., Defries, R., Asner, G. P., Barford, C., Bonan, G., Carpenter, S. R., Chapin, F. S., Coe, M. T., Daily, G. C., and Gibbs, H. K. 2005. Global consequences of land use. Science 309:570-574.

Frost, P. C., Ebert, D., and Smith, V. H. 2008. Responses of a bacterial pathogen to phosphorous limitation of its aquatic invertebrate host. Ecology 89:313-318.

Fuhrer, J. 2003. Agroecosystem responses to combinations of elevated $\mathrm{CO}_{2}$, ozone, and global climate change. Agric. Ecosyst. Environ. 97:1-20.

Heagle, A. S. 2003. Influence of elevated carbon dioxide on interactions between Frankliniella occidentalis and Trifolium repens. Environ. Entomol. 32:421-424.

Heagle, A. S., Burns, J. C., Fisher, D. S., and Miller, J. E. 2002. Effects of carbon dioxide enrichment on leaf chemistry and reproduction by twospotted spider mites (Acari: Tetranychidae) on white clover. Environ. Entomol. 31: 594-601.

Hosmer, D. W., and Lemeshow, S. 2000. Applied Logistic Regression. Wiley, Hoboken, NJ.

Huber, D., and Watson, R. 1974. Nitrogen form and plant disease. Annu. Rev. Phytopathol. 12:139-165.

Hughes, L., and Bazzaz, F. A. 1997. Effect of elevated $\mathrm{CO}_{2}$ on interactions between the western flower thrips, Frankliniella occidentalis (Thysanoptera: Thipidae) and the common milkweed, Asclepias syriaca. Oecologia 109: 286-290.

Hull, R. 2002. Matthews' Plant Virology. Elsevier Academic Press, San Diego.

Ito, D., Miller, Z., Menalled, F., Moffet, M., and Burrows, M. 2012. Relative susceptibility among alternative host species prevalent in the great plains to Wheat streak mosaic virus. Plant Dis. 96:1185-1192.

Jiménez-Martínez, E., Bosque-Pérez, N., Berger, P., and Zemetra, R. 2004. Life history of the bird cherry-oat aphid, Rhopalosiphum padi (Homoptera: 
Aphididae), on transgenic and untransformed wheat challenged with Barley yellow dwarf virus. J. Econ. Entomol. 97:203-212.

Johnson, S. N., Douglas, A. E., Woodward, S., and Hartley, S. E. 2003. Microbial impacts on plant-herbivore interactions: The indirect effects of a birch pathogen on a birch aphid. Oecologia 134:388-396.

Joutei, A. B., Roy, J., vanImpe, G., and Lebrun, P. 2000. Effect of elevated $\mathrm{CO}_{2}$ on the demography of a leaf-sucking mite feeding on bean. Oecologia 123:75-81.

Kagata, H., and Ohgushi, T. 2006. Bottom-up trophic cascades and material transfer in terrestrial food webs. Ecol. Res. 21:26-34.

Kytö, M., Niemelä, P., and Larsson, S. 1996. Insects on trees: Population and individual response to fertilization. Oikos 75:148-159.

Lacroix, C., Seabloom, E. W., and Borer, E. T. 2014. Environmental nutrient supply alters prevalence and weakens competitive interactions among coinfecting viruses. New Phytol. 204:424-433.

Leung, H., Zhu, Y., Revilla-Molina, I., Fan, J. X., Chen, H., Pangga, I., Cruz, C. V., and Mew, T. W. 2003. Using genetic diversity to achieve sustainable rice disease management. Plant Dis. 87:1156-1169.

Lim, P. O., Kim, H. J., and Gil Nam, H. 2007. Leaf senescence. Annu. Rev. Plant Biol. 58:115-136.

Luck, J., Spackman, M., Freeman, A., Griffiths, W., Finlay, K., and Chakraborty, S. 2011. Climate change and diseases of food crops. Plant Pathol. 60:113-121.

Mahler, R. L., Koehler, F. E., and Lutcher, L. 1994. Nitrogen source, timing of application, and placement: Effects on winter wheat production. Agron. J. 86: 637-642.

Michels, G., Jr., Rush, C., Whitaker-Deerberg, R., and Heidel, G. 1994. Deleterious effects of wheat streak mosaic virus infection of winter wheat on greenbug (Homoptera: Aphididae) reproduction. Southwest. Entomol. 19: 109-113.

Miller, Z., Menalled, F., Ito, D., Moffet, M., and Burrows, M. E. 2014. Impacts of crop variety and time of inoculation on the susceptibility and tolerance of winter wheat to Wheat streak mosaic virus. Plant Dis. 98:1060-1065.

Nakicenovic, N., and Swart, R. (eds). 2000. Special report on emissions scenarios, working group III, Intergovernmental Panel on Climate Change (IPCC). Cambridge University Press, Cambridge.
Navia, D., De Mendonça, R. S., Skoracka, A., Szydło, W., Knihinicki, D., Hein, G. L., Da Silva Pereira, P. R. V., Truol, G., and Lau, D. 2013. Wheat cur mite, Aceria tosichella, and transmitted viruses: An expanding pest complex affecting cereal crops. Exp. Appl. Acarol. 59:95-143.

Orloff, N., Miller, Z., Menalled, F., Burrows, M., and Mangold, J. 2013. Joint effects of biotic and abiotic stressors on winter wheat suppression of Bromus tectorum. Weed Res. 53:192-200.

Pennazio, S., and Roggero, P. 1997. Mineral nutrition and systemic virus infections in plants. Phytopathol. Mediterr. 36:54-66.

Sterner, R. W., and Elser, J. J. 2002. Ecological Stochiometry: The Biology of Elements from Molecules to the Biosphere. Princeton University Press, Princeton, NJ.

Thomas, J. A., and Hein, G. L. 2003. Influence of volunteer wheat plant condition on movement of the wheat curl mite, Aceria tosichella, in winter wheat. Exp. Appl. Acarol. 31:253-268.

Thompson, G., Brown, J., and Woodward, F. 1993. The effects of host carbon dioxide, nitrogen and water supply on the infection of wheat by powdery mildew and aphids. Plant Cell Environ. 16:687-694.

Thresh, J. 1982. Cropping practices and virus spread. Annu. Rev. Phytopathol. 20: 193-216.

Tilman, D., Cassman, K. G., Matson, P. A., Naylor, R., and Polasky, S. 2002. Agricultural sustainability and intensive production practices. Nature 418:671-677.

Tripp, K. E., Kroen, W. K., Peet, M. M., and Willits, D. H. 1992. Fewer whiteflies found on $\mathrm{CO}_{2}$ enriched greenhouse tomatoes with high $\mathrm{C}: \mathrm{N}$ ratios. HortScience 27:1079-1080

Walters, D., and Bingham, I. 2007. Influence of nutrition on disease development caused by fungal pathogens: Implications for plant disease control. Ann. Appl. Biol. 151:307-324.

Zehnder, C. B., and Hunter, M. D. 2009. More is not necessarily better: The impact of limiting and excessive nutrients on herbivore population growth rates. Ecol. Entomol. 34:535-543.

Ziska, L. H., and Runion, G. B. 2007. Future weed, pest, and disease problems. Pages 261-287 in: Agroecosystems in a Changing Climate. P. C. Newman, R. A. Carran, G. R. Edwards, and P. A. Niklaus, eds. CRC Press Taylor and Francis, Boca Raton, FL. 